\title{
Bedside surgical ligation of patent ductus arteriosus in very low birth weight premature infants: limited upper ministernotomy as an alternative approach
}

\author{
Muhammet Akyuz ${ }^{1}$, Onur Işı ${ }^{1}$, Ilker Mercan ${ }^{1}$, and Meltem Cakmak ${ }^{1}$ \\ ${ }^{1}$ Izmir Tepecik Training and Research Hospital
}

July 9, 2020

\begin{abstract}
Background: Patent ductus arteriosus is an important cause of morbidity and mortality especially in very low birth weight infants. The aim of the present study was to evaluate outcomes of bedside surgical ligation of patent ductus arteriosus via limited upper ministernotomy as an alternative approach to thoracotomy. Material and Method: A total of 23 low birth weight premature infants who underwent bedside ligation of PDA in the neonatal intensive care unit January 2017 to April 2020 , were enrolled. The patients were divided into two groups: those with thoracotomy $(n=13)$ and those with limited upper minister$\operatorname{notomy}(\mathrm{n}=10)$. These patients were evaluated retrospectively in terms of clinical and preoperative, intraoperative,postoperative parameters between the groups. Results: Mean birth weight was $1059 \pm 275$ grams in the thoracotomy group and $1035 \pm 285$ grams in the ministernotomy group. There was no statistically significant difference in the age at surgery, weight at surgery,preoperative MV support,inotropic score onset of surgery and total procedure time between the groups. There was a statistically significant difference in the hospital length of stay,postoperative MV time and complications in the intensive care unit in favor of the ministernotomy group $(\mathrm{p}=0.04, \mathrm{p}=0.03, \mathrm{p}=0.034$ respectively $)$. The study showed no statistically significant difference in the mortality rate between the two groups ( 2 patients in the thoracotomy group and 1 patient in the ministernotomy group). Conclusion:The limited upper ministernotomy is anatomically and technically feasible alternative to classical left posterolateral thoracotomy for bedside surgical PDA ligation.
\end{abstract}

\section{Hosted file}

Bedside.doc available at https://authorea.com/users/309400/articles/468256-bedside-surgicalligation-of-patent-ductus-arteriosus-in-very-low-birth-weight-premature-infants-limitedupper-ministernotomy-as-an-alternative-approach 